specimens for examination. Specimens of the timber of $W$ ellingtonia gigantea presented under the microscope a double row of opposite disks, which, as well as their central dot, were elliptical.

6. "On Ophioglossum lusitanicum, Linnæus," by Thomas Moore, F.L.S. The author remarked that the discovery of the Ophioglossum Iusitanicum, L., within thepolitico-geographical limits of Great Britain, so soon after that of the Gymnogramma leptophylla, another S. European fern, is a fact of much interest; and thought that a short account of the plant drawn up from fresh Guernsey specimens might be of some interest to those who are studying either our native Ferns or our native flora.

\title{
MISCELLANEOUS.
}

Note on the Vegetation of Mount Argaus in Cappadocia. By M. P. DE TChinatchefF.

As Mount Argæus, of which I have ascertained the height to be 3841 metres above the level of the sea, consists of a certain number of plateaux, forming so many terraces arranged one above another, with intervening slopes of greater or less abruptness, the study of the most characteristic vegetable forms of these plateaux may furnish an approximative idea of the vegetable physiognomy of the giant of Asia Minor, which had not been visited by any botanist until I ascended it in August 1848. Amongst these plateaux, of which I have indicated the respective positions in my work on the \& Géographie physique de l'Asie Mineure,' the most considerable are, that of Tékir, situated on the eastern side of the mountain, at an altitude of 2128 metres, and the three plateaux arranged in steps on its southern face, by which one ascends from the plain of Everek to the summit of the mountain. These plateaux may be designated by the following names, rising from the bottom upwards : the basaltic plateau, placed immediately above the plain of Everek, which constitutes the southern foot of the mountain; the lower plateau; and lastly, the upper plateau, which leads to the central cone, crowned by the crater, which is surrounded on the south side by a barrier of inaccessible trachytic rocks.

The great number of limpid streams which water the surface of the Tékir plateau, maintain a pretty good vegetation in that locality. Amongst the plants in flower on the 17th of August, I observed, Oxyria reniformis, R. Br. sp., Carduo deflorato aff., L., Podospermum intermedium, Solidago Virgaurea, L., Chamcemelum oreades, Boiss., Helichrysum globiferum, Boiss., Andrachne telephiö̈des, L., Lamium armenium, Boiss., Silene argaa, n. sp., Phyteuma linifolium, Boiss., Pulsatilla albana, Stev., Sibbaldia parvifolia, Willd., \&c.; as well as some species of Asperula, Odontites and Androsace, which were less characteristic.

The basaltic plateau, the dry poor soil of which is strewed with blocks of stone and pierced by projecting rocks, is only covered with 
vegetation in isolated spots: I found in flower, Plumbago europcea, Anchusa officinalis, L., variety angustifolia, Potentillae argentece affinis, Rosa, n. sp., Coronilla glauca, \&c.: the most characteristic features of the plateau, however, were Quereus nana, Populus graca (both in the shrubby state), a great number of Euphorbiacea, Erigeron alpinum, Astragalus aureus, and the Verbascum olympicum, Boiss.; the latter plant scarcely attains a height of 40 centimetres in this locality.

The lower plateau has scarcely any characteristic forms. In proportion as we ascend the steep declivity which leads from the lower to the upper plateau, the Quercus nana gradually disappears, and is replaced by the Juniperus nana, which continues to grow a little above the upper plateau, so that the limit of shrubby vegetation may be fixed (at least on the southern exposure of the mountain) at an absolute height of about 2600 metres, and consequently 137 metres above the upper plateau, the elevation of which is 2463 metres. The surface of the latter is covered with immense quantities of Verbascum chrysorrhoeos, Boiss. It was here that I observed for the first time the Jurinea depressa, Mey., a plant much sought for by the Turks on account of the musky odour which it exhales, and which has obtained for it in the neighbouring country the name of Muskgulé (musk-rose). This fine and rare Composite plant had already (18th of August) passed its period of flowering, and I had much trouble in discovering and collecting a few good specimens. The lower limit of the Jurinea depressa is consequently 2463 metres; its upper limit probably attains 2700 to 2800 metres. Associated with this plant were Daphne buxifolia, Wahl., Silene argaa, n. sp., Thymus angusti . folius, Ziziphora nummularia, n.sp., Satureia argaa, n. sp., Hieracium pannosum, Boiss, Morina persica, Astragalus aureus, Potentilla argentea, \&c. Of these plants, the Daphne, Astragalus, Potentilla, Silene and Thymus descend below 2463 metres, whilst the Ziziphora, Satureia and Hieracium keēp at this altitude, or even occasionally rise still higher. The Hieracium pannosum attains, if not the zone of perpetual snows, at least a region where these descend frequently, as was the case when I was there; its stem usually attains a height of 30 centimetres; all parts of the plant, but especially the large radical leaves, are covered with white woolly hairs to such an extent, that, when seen at a certain distance, the solitary herids, bristling with a close pappus, appear like so many balls of snow.

In ascending the precipitous side of the central cone, which rises immediately from the upper plateau, a tolerably fine vegetation is met with to an elevation of 3005 metres. On this space, that is to say, between 2463 and 3005 metres, I observed Jurinea depressa; Mey., var. sulphurea, Astragalus nummularius, Lam., Astr.chianophilus, and two other species of Astragalus; a Cotyledon, an Evax, and an Arenaria, which have not been determined ; Sibbaldia parvifolia, Willd., Polygonum alpinum, L., Cystopteris fragilis, Bernh., Myosotis palustris, Silene argae, n. sp., Sedum olympicum, Boiss., Veronica fruticulosa, L., Alopecurus vaginatus, Pall., Alsine recurva, Solidago Virgaurea, Podospermum intermedium, \&c. Of these plants, Silene 
argae, Alsine recurva, Solidago Virgaurea and Podospermum intermedium rise above 3005 metres, for I found them in the fissures of the abrupt rocks which pierce through the incline of the central cone and reach the most elevated region. On this naked slope, covered with loose cinders and with scattered bands of snow, the four lastmentioned plants are found associated with Euphorbia nicaensis, All., Scrophularia olympica, Boiss., Pyrethrum Kotschii, Boiss., and some species of Chamamelum, Saxifraga and Erigeron, which have not been determined; thus, without counting the latter, the seven species just referred to are the representatives of the highest regions of Mount Argæus, as they all attain an altitude of 3841 metres. It is interesting to observe in this number the Euphorbia niccensis and the Solidago Virgaurea, which I am in the habit of seeing so frequently in my garden in the plain of Nice. These plants, of which the horizontal development is so great, have consequently also a vertical development of 3841 metres, flourishing indifferently in the neighbourhood of the eternal snows, and beside the date-palm, the Opuntia and the Agave._Comptes Rendus, 23rd January, 1854.

On certain Statements contained in Dr. T. Williams' Papers on the Respiratory Organs of the Articulata.

To the Editors of the Annals of Natural History.

Gentremen,

London, Mareh 6, 1854.

I HAve observed with surprise and regret such a mass of erroneous statements in the papers now publishing in the 'Annals' on the Respiratory Organs of the Articulata, by Dr. T. Williams, that I write at once to say, that, at a future period, at my earliest convenience after Dr. Williams has completed his remarks on the subject of the Blood and the Respiratory Structures, I shall feel myself called upon to beg for space in your Journal to attempt to remedy the injury which these errors are likely to inflict on science by their promulgation. I hasten to inform you of this least it should be supposed that I assent to these statements.

I am, Gentlemen,

Yours very obediently,

George Newport.

\section{ON THE GENERA VOLUTELLA AND CYMBIOLA.}

It was formerly considered that the chief distinction between $\bar{V}_{0-}$ luta and Marginella of Lamarck was, that one had the shell exposed, and the other covered by the expanded and reflexed lobes of the mantle. M. D'Orbigny, in his work on the Mollusca of South America, figured the animal of Voluta angulata, and showed that that species had the mantle lobes expanded and partly covering in the shell; on this character it has been formed into a genus under the name of Volutella, for it differs from Marginella in having the expanded 


\section{$2 \mathrm{BHL}$ Biodiversity Heritage Library}

De Tchihatcheff, M P. 1854. "Note on the vegetation of Mount Argæus in Cappadocia." The Annals and magazine of natural history; zoology, botany, and geology 13, 344-346. https://doi.org/10.1080/03745485709496348.

View This Item Online: https://www.biodiversitylibrary.org/item/19611

DOI: https://doi.org/10.1080/03745485709496348

Permalink: https://www.biodiversitylibrary.org/partpdf/14357

\section{Holding Institution}

Natural History Museum Library, London

\section{Sponsored by}

Natural History Museum Library, London

\section{Copyright \& Reuse}

Copyright Status: Public domain. The BHL considers that this work is no longer under copyright protection.

This document was created from content at the Biodiversity Heritage Library, the world's largest open access digital library for biodiversity literature and archives. Visit BHL at https://www.biodiversitylibrary.org. 